\title{
Some Wild Edible and Medicinal Mushroom Species at Khartoum and Sinnar States-Sudan
}

Abdalla $\mathrm{RR}^{1 *}$, Ahmed $\mathrm{Al}^{2}$, Abdalla $\mathrm{Al}^{1}{ }^{1}$, Abdelmaboud OAA $^{1}$, Khiery NTMA ${ }^{1}$, Elriah NDA ${ }^{1}$ and Saeed MSA $^{1}$

${ }^{1}$ Department of Agriculture, Alzaiem Alazhari University, Sudan

${ }^{2}$ Department of Botany, Sinnar University, Sinner State, Sudan

\begin{abstract}
The aim of this study was to identify some wild edible and medicine species at two states of Sudan and determine its chemical composition and document traditional culture of wild mushrooms uses in some tribes of Sudan. The screening provided fourteen wild species. Six selected edible and medicinal species were further subjected to chemical analysis to determinate their moisture content, protein, fat, carbohydrate, ash, fiber and macro elements (potassium, sodium, calcium, magnesium and phosphorus). At Khartoum state three of mushrooms classified as edible or of medicinal value namely Agaricus bisporus, Ganoderma lucidum and Podaxis pistillaris. At sinner state two mushrooms considered edible namely; Agaricus bisporus and Pluteus umbrosus var. albus and three considered of medicinal value, namely Ganoderma lucidum, Podaxis pistillaris and Grifola frondosa and fungi was identified of dual function Calvatia cyathiformis. The result show that Agaricus bisporus recorded a highest value of moisture, fat, ash and calcium, Calvatia cyathiformis recorded a highest value of protein, Grifola frondosa recorded a highest value of carbohydrate, Ganoderma lucidum recorded a highest value of fiber, Pluteus umbrosus var. albus recorded a highest value of potassium, Podaxis pistillaris recorded a highest value of sodium, phosphorus and magnesium.
\end{abstract}

Keywords: Chemical composition; Edible; Medicine mushroom; Sudan

\section{Introduction}

In many parts of the world, particularly developing countries, people have problems in producing sufficient food. Poverty is increasing rapidly in these areas which necessitate the introduction of new crops to alleviate this poverty and to mitigate this food gap. One of these interventions is the introduction and growing of mushrooms as vegetable crop [1].

FAO reported that there are great potential of mushrooms in African forests and other landscapes which is largely untapped [2]. The long periods of warm weather and air moisture combine to provide excellent conditions for the production of mushrooms in African forest. There are several varieties, including those which grow on decaying roots, dead wood, termite mounds or directly on cultivated land which can play a pivotal role in transforming lively hood security of local farmers in Africa. Wild mushrooms are required for breeding better high yielding mushrooms with desirable traits for industry or for research purposes [3,4].

The wild mushroom at Sudan is not clearly identified. The aim of this study is to explore some wild edible and medicinal mushroom species around Khartoum and sinner states. The study documents the value of their chemical composition and traditional culture of consuming wild mushrooms in tribal area of Sudan. The problem of this study centered on the fact that wild mushroom in Sudan are not clearly identified. The species that edible are not well known (Figure 1).

\section{Material and Methods}

\section{Areas of study}

The areas of study are represented in Figure 1. It include Khartoum state and el Suki locality at Sinnar state. Greater Khartoum is located between latitudes $15^{\circ} 26^{\prime}$ and $15^{\circ} 45^{\prime} \mathrm{N}$ and longitudes $32^{\circ} 25^{\prime}$ and $32^{\circ} 40^{\prime}$ E. According to Eltayeb, the rainy season covers the period from July to September; annual rainfall ranges between 110 and $200 \mathrm{~mm}$ [5]. The relative humidity around Khartoum records a mean of 29 percent.

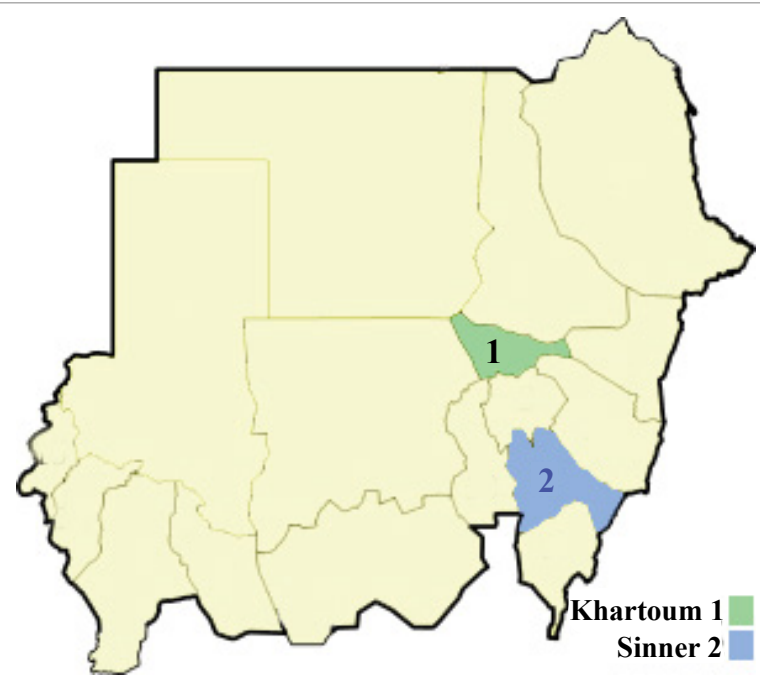

Figure 1: Areas of study.

El Suki locality is located between latitude: $12^{\circ}-13^{\circ} \mathrm{N}$, longitudes: $33^{\circ}-34^{\circ}$ E. Himada reported that the average rainfall is $424 \mathrm{~mm}$ per annum, and the heaviest ones normally occur during period from July to September (112.1, 148.9 and $75.9 \mathrm{~mm}$, respectively) [6]. The mean relative humidity ranged between $26 \%$ in April and reached a

*Corresponding author: Abdalla RR, Departrment of Agriculture, Alzaiem Alazhari University, Sudan, Tel: 00249901111466; E-mail: ran7ram7.com@gmail.com

Received October 11, 2016; Accepted December 15, 2016; Published December 22, 2016

Citation: Abdalla RR, Ahmed Al, Abdalla Al, Abdelmaboud OAA, Khiery NTMA, et al. (2016) Some Wild Edible and Medicinal Mushroom Species at Khartoum and Sinnar States-Sudan. J Microb Biochem Technol 8: 503-506. doi: 10.4172/19485948.1000333

Copyright: @ 2016 Abdalla RR, et al. This is an open-access article distributed under the terms of the Creative Commons Attribution License, which permits unrestricted use, distribution, and reproduction in any medium, provided the original author and source are credited. 
maximum of $62 \%, 69 \%$ and $65 \%$ during the rainy season; July, August and September, respectively.

\section{Samples}

The survey of wild mushrooms include recording taking photos and recording notes on phenotypic traits such as shape ,texture, smell, cap size, cap margin, gill color, gill attachment, gill spacing, stalk size, stalk shape, stalk interior, stalk surface, ring and volva. The researchers also recorded notes on mushroom ecology. Fresh mushroom samples were chemically tested for color change using $\mathrm{KOH}$ (Potassium Hydroxide) $4 \%$.

Local people were interviewed about wild local mushroom culture, consumption, collection and nutritional value. Identification of wild mushroom species were done using different keys such as mycokey software program, mushroom expert web site, mykoweb web site, mycobank web site [7-9].

\section{Chemical composition}

Analysis of moisture content was done on fresh weight basis. Moisture content was determined following the method of A.O.A.C (Association of Official Analytical Chemists) f Total Fat, Ash and Protein determined according to A.O.A.C $[10,11]$. Crude fiber was measured using the Pearson method. Carbohydrate determined by subtracting [12]. Dry ash was recorded using Pearson [13]. Phosphorus content was determined by the vanadate-molydate-yellow method [14]. The density of the colour was read at $470 \mathrm{~nm}$ using spectrophotometer (Jenway 6305 UV/Vis). Potassium and Sodium: according to the AOAC using flame photometer (Jenway pfp7) [10]. Calcium and Magnesium determination according to Kalra [15].

\section{Results}

Mushrooms known with different names at Sudan; in Northern Sudan mushroom is known as "Wad Al Werda" and that meaning the agent that causes fever, in other parts of Northern Sudan such as "Dongolla", people tend to eat mushroom with traditional local receipt cooked using okra and they name it "Goroo". Some Nilotic tribes name wild mushroom as "Barnoog", the name has also been noticed in some local proverb. A proverb such as "Barnoog without root" is used to describe or insulting those who do not have definite tribe. Some tribes know mushroom as "Gowangy", they eat it after drying it as porridge. In areas of Central and Eastern Sudan, some people consume mushroom and name it as "Al-Afan" or Abo- Elefeen or "Afan Al-Watta" which is synonymous to the meaning of mould in the English language. Some other people in Darfur call it "Sindanet alard" which means the dowel of the land. Some other call it Flata's bread after the Flata tribe of west
Sudan. Interviews with locals in areas around Sinnar state revealed that some people eat "Abo zomo". They use it in a proverb "Abo zomo is bridal food". People in Sinnar used to see Abo zomo grow on "Alqantoor", dome of sand built by termite insect, some other kind of Abo zomo grow on soil decomposed at Ronga forest at Sinnar which can be classified as agro-forestry ecology. This clearly shows that people recognize different edible mushroom species under one local name. Other name of wild mushrooms in Sinnar is "Laham Al Watta" which means the flesh of the land, other names around Sinnar State includes "Lahm el fertit" referring to it as a food for pigs. Om Deriwa is another locally identified edible mushroom around Sinnar state. The quality and the value of consumption of this local mushroom are well documented in the traditional knowledge of locals and best represented in the old proverb (Om deriwa lele bit alheliwa); which means Om deriwa for beautiful ladies. They use its spores for cosmetic aspect also. We can concluded that most Sudanese know mushroom in the name of "Wad Al-Watta" that mean "the son of the land", another famous name for mushroom in Sudan is "Osh elgorab" which means the nest of the crow.

The study assessed quantitative data on physical characteristics of fourteen wild species found in Khartoum and Sinnar States. Six edible and medicinal species were further subjected to chemical analysis to determinate their moisture content, protein, fat, carbohydrate, ash, fiber the study also estimated the macro elements (potassium, sodium, calcium, magnesium and phosphorus) using standard techniques. Around Khartoum State three of mushrooms classified as edible or of medicinal value namely; Agaricus bisporus, Ganoderma lucidum and Podaxis pistillaris. At El Suki locality-Sinner State, two mushrooms considered edible namely; Agaricus bisporus and Pluteus umbrosus var. albus; and three considered of medicinal value, namely Ganoderma lucidum, Podaxis pistillaris and Grifola frondosa) and one of dual function Calvatia cyathiformis. Other wild species were identified at Khartoum state: Agaricus placomyces, Aleuria aurantia, Abortiporus biennis and Pisolithus tinctorius, at Sinnar state Lentinus tigrinus and Entoloma cephalotrichum. Coprinus disseminates and Mutinus ravenelii have been found at Khartoum and Sinnar states.

The study is presented as quantitative data on the morphological character and chemical constituent of these six edible and medicinal wild mushrooms (Tables 1 and 2).

The result show that Agaricus bisporus recorded a highest value of moisture, fat, ash and calcium, Calvatia cyathiformis recorded a highest value of protein, Grifola frondosa recorded a highest value of carbohydrate, Ganoderma lucidum recorded a highest value of fiber, Pluteus umbrosus var. albus recorded a highest value of sodium and potassium, Podaxis pistillaris recorded a highest value of phosphorus and magnesium. The standard deviation of proximate analysis recorded

\begin{tabular}{|c|c|c|c|c|c|c|c|}
\hline Species & $M-f w$ & M-dw & \multirow{2}{*}{$\begin{array}{c}C P \\
(N \times 4.38)\end{array}$} & \multirow[t]{2}{*}{ CF } & \multirow[t]{2}{*}{$\mathrm{CH}$} & \multirow[t]{2}{*}{$\mathrm{CFi}$} & \multirow[t]{2}{*}{ Ash } \\
\hline & & & & & & & \\
\hline Agaricus bisporus & 90.98 & 14.07 & 21.35 & 3.50 & 20.75 & 14.33 & 26.00 \\
\hline Calvatia cyathiformis & 86.71 & 7.20 & 40.47 & 3.05 & 24.83 & 16.25 & 8.20 \\
\hline Ganoderma lucidum & 81.00 & 8.10 & 9.78 & 1.28 & 35.94 & 40.23 & 4.67 \\
\hline Grifola frondosa & 69.67 & 6.97 & 9.49 & 2.10 & 52.74 & 14.97 & 13.73 \\
\hline Podaxis pistillaris & 83.71 & 8.40 & 24.12 & 2.22 & 34.13 & 13.00 & 18.13 \\
\hline Pluteus umbrosus var. albus & 89.26 & 7.33 & 19.14 & 2.20 & 29.80 & 16.03 & 25.50 \\
\hline Mean & 83.56 & 8.68 & 20.73 & 2.39 & 33.03 & 19.14 & 16.04 \\
\hline Standard deviation & 7.04 & 2.46 & 10.41 & 0.71 & 11.19 & 9.50 & 8.05 \\
\hline Coefficient of Variation (\%) & 8.42 & 28.34 & 50.21 & 29.70 & 33.87 & 49.63 & 50.18 \\
\hline
\end{tabular}

M-fw: Moisture of Fresh Weight; M-dw: Moisture of Dry Weight; CP: Crude Protein; CF: Crude Fat; CH: Carbohydrate; CFi: Crude Fiber; A: Ash.

Table 1: Proximate composition (g/100 g dry weight) of some edible and medicinal mushrooms in Khartoum and Sinnar states. 


\begin{tabular}{|l|c|c|c|c|c|}
\hline \multirow{2}{*}{\multicolumn{1}{|c|}{ Species }} & Na & K & P & Ca & Mg \\
\cline { 2 - 6 } & \multicolumn{4}{|c|}{ ppm } \\
\hline Agaricus bisporus & 1.82 & 20.71 & 8.50 & 34.00 & 0 \\
\hline Calvatia cyathiformis & 1.04 & 8.74 & 8.09 & 4.00 & 10.00 \\
\hline Ganoderma lucidum & 0.20 & 2.43 & 3.63 & 4.00 & 8.00 \\
\hline Grifola frondosa & 0.35 & 4.35 & 3.35 & 11.00 & 2.00 \\
\hline Podaxis pistillaris & 4.82 & 21.69 & 11.19 & 13.00 & 11.00 \\
\hline Pluteus umbrosus var. albus & 3.52 & 32.71 & 10.84 & 5.00 & 0 \\
\hline Mean & 1.96 & 15.11 & 7.60 & 11.83 & 7.75 \\
\hline Standard deviation & 1.69 & 10.81 & 3.12 & 10.51 & 3.49 \\
\hline Coefficient of Variation & 86.22 & 71.54 & 41.05 & 88.84 & 45.03 \\
\hline
\end{tabular}

Table 2: Mineral constituents of some edible and medicinal mushrooms in Khartoum and Sinnar states.

a high level for samples in carbohydrate 11.19 and recorded a low level in crude fat 0.71 .

Crude protein, ash and crude fiber, (50.21), (50.18) and (49.63), respectively recorded the highest coefficient of variation which making these characters the highest characters that show great variability in proximate analysis.

The standard deviation of minerals analysis recorded a high level for samples in potassium (10.81) and recorded a low level in sodium (1.69).

Calcium, sodium and potassium, (88.84), (86.22) and (71.54), respectively recorded the highest coefficient of variation which making these characters the highest characters that show great variability in analysis for minerals content.

These results showed that these species of mushrooms have no morphological differences within the same species between Khartoum and Sinnar states. These mushrooms are highly nutritive and can play a vital role in lifting up the social and livelihood status of local people.

\section{Discussion}

The study revealed three different ecology for edible and medicinal mushroom. Ronga forest in Sinnar can be classified as agro-forestry ecology and mushroom relay on rich decaying and living hardwood. El suki locality has pastoralism activity indicating the availability of organic and manure of animal origin along with dry pastoral plants. In Khartoum samples were collected from Nile River bank and The National Plant Garden. This is areas with modified microclimate rich in decaying wood and organic matter. The three ecology has limited mushroom distribution and feeding habits. Agaricus bisporus, Calvatia cyathiformis, Pluteus umbrosus var. albus are Saprobic. Ganoderma lucidum, Grifola frondosa parasitic on living hardwoods and saprobic on the deadwood. Podaxis pistillaris grow along dry roadsides of the desert regions, mycokey online program [16]; mushroom expert web site and Mykoweb web site. According to Kurtzmanr, the age of the mushrooms, the growing environment and the post-harvest environment can all have a large effect on both moisture and solid matter [17]. The moisture content in this study ranged from $69.67 \%$ to $90.98 \%$ in generally the moisture content in this study is rather low than previous studies; $78.3 \%-90.5 \%$ of Agaricus bisporus, Crisan and Sands [18]. 90.76\% of Agaricus bisporus cap, $90.01 \%$ of Agaricus bisporus stipe, Nasiri et al [19]. 92.47\% of Grifola frondosa on Sawdust, and $90.41 \%$ Grifola frondosa on $\log$ [20]. This may be due to that the samples spent about $24-72 \mathrm{~h}$ before measuring the moisture especially the samples orginated from Sinnar. The result showed the moisture content of Grifola frondosa and Ganoderma lucidum 69.67-81.00\%, respectively and that because they were mature enough to be tough not fleshy. The fat content of this study according to Table 1 ranged between $1.28 \%$ in Ganoderma lucidum to $3.50 \%$ in Agaricus bisporus. Previous studies showed low content of fat as compared to carbohydrates and proteins. 1.7\%-8.0\% of fat in Agaricus bisporus, Crisan and Sands [18]. 1.3\%-5.8\% of fat in Agaricus bisporus, OECD [21]. 0.1\% of Calvatia cyathiformis, Aletor [22]. 5.13\% of fat in Ganoderma lucidum, Mau et al [23]. 1.52\% of fat in Ganoderma lucidum, Ogbe and Affiku [24]. $1.46 \%$ of fat in Grifola frondosa on Sawdust, and $2.40 \%$ fat in Grifola frondosa on log, Tabata et al [20]. Calvatia cyathiformis recorded $3.05 \%$ of fat in this study and the same mushroom recorded $0.1 \%$ crude fat in Aletor study, that because Aletor used fully mature washed - air dried sample and we used small age oven-dry sample [22]. The large amount of crude protein that has been recorded in this study found in Calvatia cyathiformis $40.47 \%$. Aletor found that the percentage of crude protein in fully mature washed - air dried sample of Calvatia cyathiformis is $13.2 \%$ but in this study crude protein of small age ovendry of the same mushroom is $40.47 \%$ and this result is closely to $46 \%$ according to Crisan and Sands [18,22]. The coefficient 4.38 used to multiply nitrogen value in protein in this study. The least amount of protein at this study was found in Grifola frondosa, Ganoderma lucidum 9.49\%-9.78\%, respectively. Mau et al recorded 7.92\% crude protein of Ganoderma lucidum and this is in conformity to report by Mau et al who pointed out that medicinal mushrooms usually contains less amounts of proteins [23]. In this study crude fiber contain average $13.00 \%$ of Podaxis pistillaris and $40.23 \%$ of Ganoderma lucidum. Mau et al recorded 59.16\% fiber of Ganoderma lucidum this high amount of Ganoderma lucidum fiber used to obtain folk medicine in china [23]. Mau et al describe how to use G. lucidum in folk medicine: mushrooms were usually cooked in boiling water for several hours and the concentrate thus obtained was used as folk medicine [23]. Therefore, a high amount of fiber, which was acid-alkali and alcohol-insoluble, was less effective in taste than water-soluble components, which also were taste components. Ogbe and Affiku recorded 7.77\% fiber of Ganoderma lucidum Ogbe and Affiku used red open caps mushroom were collected from decaying logs of woods and tree stumps, this study used fully mature mushroom collected from decaying logs [24]. The highest amount of Carbohydrate in this study recorded in Grifola frondosa $52.74 \%$, Tabata et al recorded $80.47 \%$ which consider a high amount of carbohydrate of cultivated Grifola frondosa grown on sawdust and 71.95\% carbohydrate of cultivated Grifola frondosa grown on log [20]. That shows Grifola frondosa is rich in carbohydrate. This study showed that Podaxis pistillaris recorded a highest value of $\mathrm{Na}, \mathrm{P}$, and $\mathrm{Mg}$ and had a good value of $\mathrm{K}$ and $\mathrm{Ca}$. Grifola frondosa recorded a lowest value of $\mathrm{P}$ and $\mathrm{Mg}$. In general sodium is low for all samples. Agaricus bisporus was very rich with $\mathrm{Ca}$ and Pluteus umbrosus var. albus was very rich with K. Pluteus umbrosus var. al bus and Agaricus bisporus had a very little amount of $\mathrm{Mg}$ so that they did not gave reading when titrated with EDTA. Kurtzmanr mentioned that a number of minerals in mushrooms are desirable [17]. Sodium is generally low, potassium is high and iron is high. Phosphorus is good, but not outstanding. Some minerals are controlled by the organism and others by the substrate. Apparently, calcium is controlled by the organism and most likely sodium is controlled by the substrate. However, if the osmotic pressure of the substrate becomes high, it is the growth of the mushrooms that will be reduced by the substrate. Vetter reported that sodium in A. bisporus is the only mineral element occurring at higher levels in the stipe than in the cap [25]. Other minerals and trace elements are generally found in the stipe at lower or equal levels to those in the cap. Kagawa reported that Grifola frondosa fruiting body is rich in $\mathrm{K}$ and $\mathrm{P}$, and contains lesser amounts of $\mathrm{Mg}, \mathrm{Ca}, \mathrm{Na}$ and $\mathrm{Zn}$ [26]. According 
Citation: Abdalla RR, Ahmed Al, Abdalla Al, Abdelmaboud OAA, Khiery NTMA, et al. (2016) Some Wild Edible and Medicinal Mushroom Species at Khartoum and Sinnar States-Sudan. J Microb Biochem Technol 8: 503-506. doi: 10.4172/1948-5948.1000333

to Elia, the daily reference nutrient intake (RNI) for human of calcium and phosphorus is $17.5 \mathrm{mmol}$ and for sodium and potassium are 70 and $90 \mathrm{mmol} /$ day, respectively, and the RNI of magnesium is 12.3 $\mathrm{mmol} /$ day for men and $10.9 \mathrm{mmol} /$ day for women [27].

This study is considered pioneer in throwing light on some kinds of wild species which can be used as edible or medicinal mushrooms of Sudan and it documented traditional culture of wild mushrooms uses in some tribes of Sudan.

This study recommend to enter commercial varieties and wild spp. to the production cycle to help farmers escape the consequence of seasonality of income, bring new uses to largely untapped agricultural waste and provide a model project for microfinance in Sudan. Wild mushroom still have a wide field of research at Sudan, this study recommend searching the area of identification, cultivation, breeding, medicinal and industrial purposes of wild mushrooms at Sudan.

\section{Acknowledgement}

This work was possible due to generous funding by DFID-UK Government under Delphi program, administrated by the British Council Office at KhartoumSudan. The assistant and technical support by the Agriculture College PuneMahatma Phule Krishi Vidyapeeth-India is much appreciated.

\section{References}

1. Badr A (2005) Mushroom growers' handbook 2. Shiitake cultivation. Small scale oyster mushroom cultivation in Egypt. Pest management department, Tanta, Egypt.

2. FAO (2000) Food supply situation and crop prospects in Sub-Saharan

3. Chang ST, Miles PG (2004) Mushrooms. Cultivation, nutritional value, medicinal effect and environmental impact. 2nd Ed. CRC Press, London.

4. Oei Peter (1996) Mushroom cultivation. With special emphasis appropriate techniques for developing countries. Tool publications, The Netherlands.

5. Eldin EG (2003) Urban slums reports: The case of Khartoum, Sudan, Department of Geography, Faculty of Arts University of Khartoum, Sudan.

6. Himada EME (2012) The Ecological distribution and environmental physiology of saw scaled viper echis carinatus Elsuki locality, at Sennar State, Institute of Environmental Studies, University of Khartoum, Sudan.

7. Bill R (2006) Field guide to the wild mushrooms of Pennsylvania and the midAtlantic Pennsylvania State University Press, Pennsylvania.

8. Huffman DM, Tiffany LH, Knaphus G, Healy RA (2008) Mushrooms and other fungi of the midcontinent united states, University of lowa Press, China.

9. Kent M, McKnight V (1987) Peterson field guides mushrooms, Houghton Mifflin Company Boston New York, USA.
10. AOAC (1984) Association of official analytical chemists. Official Methods of Analysis, $16^{\text {th }}$ edn. Washington D.C.

11. AOAC (2005) Association of official analytical chemists. Official Methods of Analysis, $18^{\text {th }}$ edn. Washington D.C.

12. Pearson D (1970) The chemical analysis of food J. and A. Churchill, 104 Gloucester place-London.

13. Pearson ND (1981) The chemical analysis of food H. Egan, R.S. Kirk and R.S Sawyer (eds), $18^{\text {th }}$ edn. Churchill Livingstone, New York, London.

14. Chapman HD, Pratt FP (1982) Method of analysis of soil, plant and water. $2^{\text {th }}$ edn. University of california agriculture division, USA: 169-170.

15. Kalra YP (1971) Methods used for soil, plant and water analysis at the soils laboratory of the Manitoba-Saskatchewan region, Canadian fores try service department of the environment, Alberta, Canada.

16. Petersen JH, Thomas L (2014) Mycokey software program, Denmark.

17. Kurtzmanr RH (2005) Mushroom sources for modern western medicine Micologia A plicada International 17: 21-33.

18. Crisan EV, Sands A, Chang ST, Hayes WA (1978) Nutritional value. The biology and cultivation of edible mushrooms. New York Academic Press, Canada.

19. Nasiri FB, Tarzi G, Bassiri AR, Hoseini SE, Aminafshar M (2013) Comparative study on the main chemical composition of button mushrooms (Agaricus bisporus) cap and stipe. Journal of Food Biosciences and Technology 3: 41-48.

20. Tabata T, Yoshio Y, Tetsuya O (2004) Comparison of chemical compositions of maitake (Grifola frondosa (Fr.) S. F. Gray) cultivated on logs and sawdust substrate. Food Sci Technol Res 10: 21-24.

21. OECD (2007) Series on the safety of novel foods and feeds, No. 15. Consensus document on compositional considerations for new varieties of the cultivated mushroom Agaricus bisporus: Key food and feed nutrients, anti-nutrients and toxicants.

22. Aletor VA (1995) Compositional studies on edible tropical species of mushrooms. Food Chem 54: 265-268.

23. Jeng-Leun M, Lin HC, Chen CC (2001) Non-volatile components of severa medicinal mushrooms. Food Res Int 34: 521-526.

24. Ogbe AO, John P, Affiku (2012) Effect of Polyherbal Aqueous Extracts (Moringa oleifera, Gum Arabic and wild Ganoderma lucidum) in comparison with antibiotic on growth performance and haematological parameters of broiler chickens. Res J Recent Sci 1: 10-18.

25. Vetter J (1994) Mineral elements in the important cultivated mushrooms Agaricus bisporus and Pleurotus ostreatus. Food Chem 50: 277-279.

26. Kagawa K (1989) Standard tables of food composition in Japan:184, T. Muratsubaki, K. Sayama, and K. Sato, Nippon Shokuhin Kogyo Gakkaishi 33: 181.

27. Elia M (2005) Nutrition. In Clinical Medicine, 4th edition. Kumar and Clark (Edn). W.B. Saunders Itd. USA, UK, pp: 229-264. 